\title{
Cohabitation and divorce across nations and generations
}

\author{
Kathleen Kiernan
}

\section{Contents}

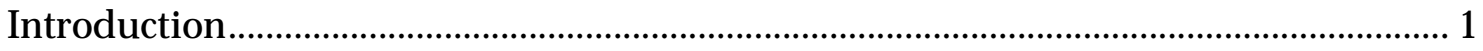

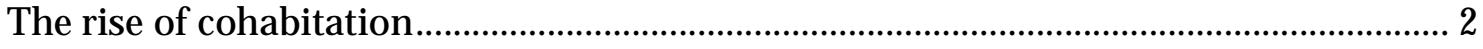

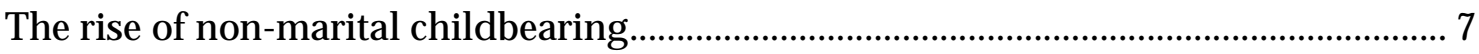

Parental divorce and children's partnership and parenthood behaviour .................... 12

Parental divorce, and partnership dissolution ............................................................... 14

Longitudinal analysis of parental separation............................................................... 16

Timing of parental separation and partnership and parenthood behaviour ............... 17

Pre-separation attributes ................................................................................................ 21

Parental separation: youthful parenthood, solo motherhood and lone parenthood . 24

Parental separation and partnership outcomes ............................................................ 27

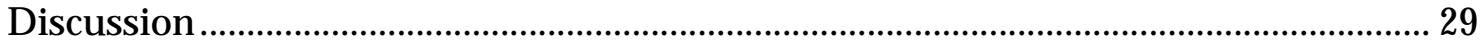

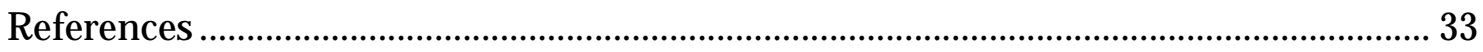

CASEpaper 65

March 2003
Centre for Analysis of Social Exclusion

London School of Economics

Houghton Street

London WC2A 2AE

CASE enquiries - 02079556679 


\section{Centre for Analysis of Social Exclusion}

The ESRC Research Centre for Analysis of Social Exclusion (CASE) was established in October 1997 with funding from the Economic and Social Research Council. It is located within the Suntory and Toyota International Centres for Economics and Related Disciplines (STICERD) at the London School of Economics and Political Science, and benefits from support from STICERD. It is directed by Howard Glennerster, John Hills, Kathleen Kiernan, Julian Le Grand, Anne Power and Carol Propper.

Our Discussion Paper series is available free of charge. We also produce summaries of our research in CASEbriefs, and reports from various conferences and activities in CASEreports. To subscribe to the CASEpaper series, or for further information on the work of the Centre and our seminar series, please contact the Centre Administrator, Jane Dickson, on:

$\begin{array}{ll}\text { Telephone: } & \text { UK+20 } 79556679 \\ \text { Fax: } & \text { UK+20 } 79556951 \\ \text { Email: } & \text { j.dickson@lse.ac.uk } \\ \text { Web site: } & \text { http://sticerd.lse.ac.uk/Case }\end{array}$

(C) Kathleen Kiernan

All rights reserved. Short sections of text, not to exceed two paragraphs, may be quoted without explicit permission provided that full credit, including (c) notice, is given to the source. 


\title{
Editorial Note and Acknowledgements
}

Kathleen Kiernan is Professor of Social Policy and Demography and a co-director of CASE. The Economic and Social Research Council UK provided the funding for this project. The ESRC Data Archive supplied the British Household Panel Survey, The National Sexual and Lifestyles Survey and the pre-2000 BCS70 data as well as the Eurobarometer data. A special thanks goes to Peter Shepherd at the Centre for Longitudinal Studies at the Institute of Education for providing the data for the 2000 wave of BCS70. The Fertility and Family Survey data were supplied by the Population Activities Unit at the UN Economic Commission for Europe at Geneva. Thanks are also due to the Advisory Group of the FFS programme of comparative research for permission granted under identification number 06 and to Statistics Sweden to use the FFS data in this study. This paper is also published as a chapter in Chase-Lansdale, P.L., Kiernan, K.E. and Friedman, R. (eds.), Human Development across Lives and Generations: The potential for change, Cambridge University Press (forthcoming).

\begin{abstract}
Parental divorce has been an increasing experience amongst the generations of children born since the 1970s in European countries. This study analyses data on the partnership and parenthood behaviour of those children who experienced parental separation during childhood for nine Western European nations, as well as Britain and the USA. Across all nations the hallmarks of the adult demographic behaviour of children who experienced parental divorce (compared with those who did not) are that they are more likely to form partnerships and to become parents at a young age; they are more likely to opt for cohabitation over marriage; they are less likely to have their first child within marriage; and their own partnerships and marriages are in turn more likely to terminate. Recently available data from the 1970 cohort was also used to search for prior factors that might throw light on why the partnership and parenthood behaviour of children who had experienced parental separation might differ from their peers without such an experience.
\end{abstract}

Keywords: Divorce, parental divorce, cohabitation, comparative study, longitudinal, inter-generational

JEL number: J12 


\section{Introduction}

Across many western nations there have been dramatic changes in partnership behaviour, most noticeably the rise of cohabitation and divorce. Until recently for the majority of couples, marriage heralded the start of first union, children were born and reared within marriage, and death typically terminated the marriage. Over recent decades marriage has been transformed: with the rise in cohabitation and non-marital childbearing it is no longer the exclusive marker of first union nor the pre-eminent context within which children are born; and life-long marriage has been eroded by divorce (Kiernan, 2001). In this chapter we examine these developments for a set of European nations and the United States, looking at how they are connected as well as their implications for children, families and societies. Our perspective is both comparative and cross-generational.

The rise of cohabitation is undoubtedly amongst the most dramatic and rapid changes in partnership behaviour in recent times and is increasingly receiving attention from social scientists and policy makers (Waite et al, 2000; Booth and Crouter, 2002; International Journal of Law, Policy and Family, 2001). In the first part of this chapter we investigate how far cohabitation has taken hold across nations. Data from a wide range of surveys including Eurobarometer Surveys, European Fertility and Family Surveys (FFS), the US National Survey of Family Growth and the British Household Panel Survey are used to examine a number of issues. Firstly, we provide a picture of the incidence of cohabitation and marriage across nations and also examine the changes that have occurred across generations in partnership behaviour. We show the extent to which people commence their first union with a marriage and how this has changed over time. Secondly, we move our focus to parenthood and examine the partnership context within which children are born in terms of whether they are born within or outside of marriage. For this latter group we make a further important distinction between children born to cohabiting parents and those born outside of a co-residential partnership. Thirdly, we investigate whether the partnership context within which a child is born enhances or reduces the risk of them seeing their parents separate. 
Parental divorce has been an increasing experience amongst the generations of children born since the 1970s in northern European countries, as it was for the generations born since the 1960s in the USA, and from whose experiences much of our knowledge on this topic emanates (Hetherington, forthcoming). Parental separation and divorce is increasingly being experienced by the generations born during the 1980s in many other European countries. It has been shown for the USA and Great Britain that children who experienced parental divorce are more likely than their contemporaries that grew up with both their parents to form partnerships and become parents at an early age, to cohabit and have children outside marriage and more likely to experience partnership dissolution themselves (Thornton, 1991 (USA); Kiernan, 1992; Cherlin, Kiernan and Chase-Lansdale 1995 (GB)). In the second part of the chapter we enquire whether these legacies pertain in other nations and indeed find that these associations are quite robust across nations.

In the final section of the chapter we go one step further and try to unearth some of the mechanisms that might account for the association between parental divorce and the later demographic behaviour of their children. Here we use longitudinal data for a British birth cohort born in 1970 followed up from birth to the present time, and who have just passed through their prime family formation ages to examine a number of issues. We assess the extent to which parental separation during different periods of childhood and early adulthood has longer-term consequences for partnership formation and dissolution and parenthood behaviour in adulthood. We also assess whether the associations that we find are tempered when we take into account child and family characteristics prior to the separation of the parents.

The discussion section summarises and draws out some of the connections and implications arising from our comparative and longitudinal analyses.

\section{The rise of cohabitation}

A so-called "golden age" of marriage prevailed in Western nations from the 1950s up to the 1970s (Festy, 1980), a period when marriage was youthful and almost universal. This pattern of marriage receded during the 1970s. Since when, marriage rates have declined, average ages at 
marriage have increased and marriage is being rejected by a growing minority, trends that continue to the present day. Undoubtedly, one of the important engines behind the decline in marriage rates and a movement to a later age at marriage is the rise in cohabitation that has occurred, particularly since the beginning of the 1980s, in many western countries.

To provide a guide to the incidence of cohabitation and the popularity of marriage across European nations we used data from a series of Eurobarometer Surveys carried out in the 15 member States of the European Union in 1998, 1999 and 2000 (European Commission, 1998, $1999,2000)$. In an attempt to reduce variation due to small sample sizes we combined the data from these three years. Eurobarometer Surveys are primarily opinion surveys carried out under the auspices of the administration of the European Union and we should bear in mind that data from such surveys are unlikely to be as accurate as those obtained in dedicated family and fertility surveys, but they probably reflect the relative position of different European countries in these developments.

Figure 1: Marital status distributions 25-34 year olds: European Union combined data 1998-2000

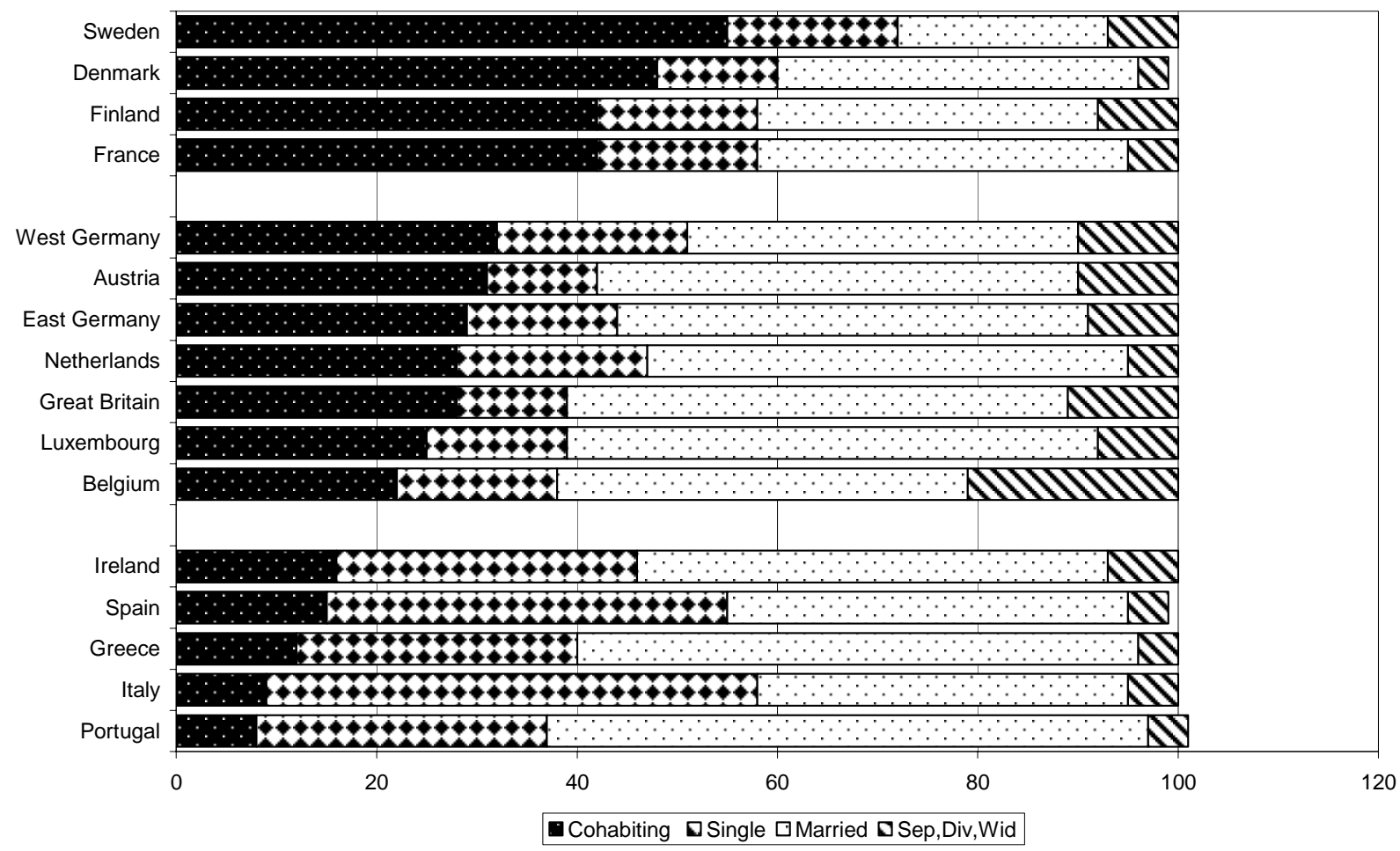


Figure 1 shows the combined proportions of men and women aged 2534 years in the 15 European Community countries who were cohabiting, married, single or separated/divorced/widowed at the time of the surveys in 1998, 1999 and 2000. It is clear from Figure 1 that there is a good deal of diversity across European states in the incidence of cohabitation. Three broad groupings can be seen. Cohabitation is strikingly common in the Nordic countries of Denmark, Sweden and Finland, and France also has relatively high proportions cohabiting. There is a middle group of countries including the Benelux countries (the Netherlands, Belgium and Luxembourg), Great Britain, West and East Germany, and Austria with intermediate levels of cohabitation. Evidence from USA surveys suggests that the USA would also fall into this grouping (Raley, 2000). At the other extreme is the set of Southern European countries and Ireland, where cohabitation is less common than in other European nations.

It is also clear from these data that there is a good deal of variation in the proportions of young people in marital unions. Marriage is most popular in the southern European countries of Greece and Portugal but this is much less the case in the other southern European countries of Italy and Spain, which have low proportions in marital unions and the highest proportions single. In the Nordic countries as well as in France, cohabitation is more popular than marriage at these ages whereas marriage is seemingly more popular in countries such as Austria, Netherlands, Great Britain, and Luxembourg.

Until recently, more detailed data on cohabitation tended to be scarce and generally emanated from ad hoc surveys. This presented problems for comparative analyses as sample sizes, coverage and definitions could vary. However, during the 1990s more information from standardised questionnaires became available from a series of Fertility and Family Surveys carried out in the main in the first half of the 1990s under the auspices of the UN Economic Commission for Europe (ECE) (United Nations, 1992). Similar data had been collected in the 1995 US National Survey of Family Growth and the 1992 wave of the British Household Panel Survey. These surveys included partnership histories that incorporated dates of marriages and any other co-residential heterosexual intimate relationships. Such histories permit more in depth examinations of partnership formation and dissolution than can be gleaned from vital registration data or cross-sectional surveys that only include current status information. 
Figure 2: Percentage first unions beginning with cohabitation by age group

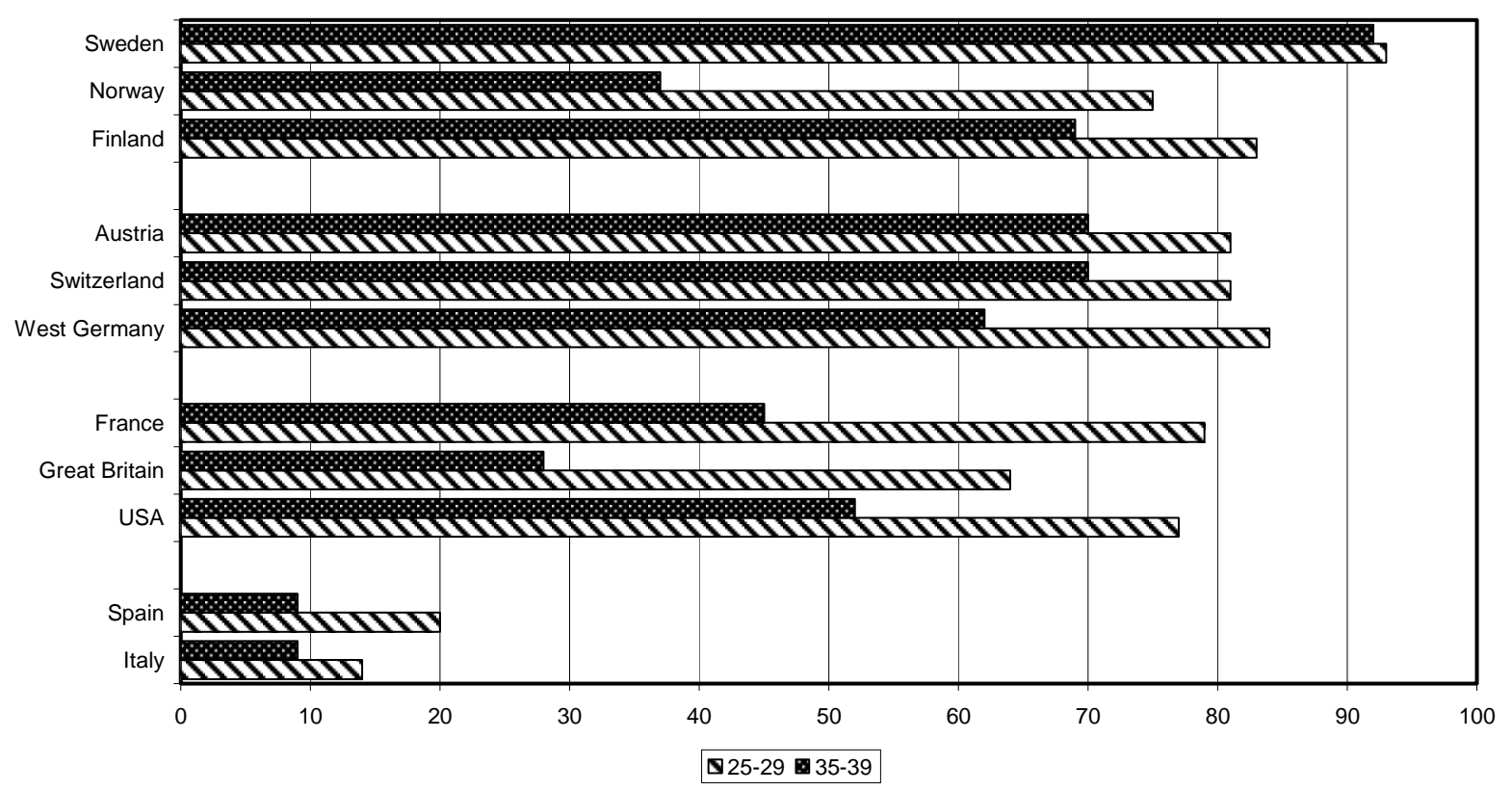

To illustrate the rise in cohabitation and variation across nations in this development Figure 2 shows the proportions of women who commenced their first co-residential partnership with cohabitation (the complement is the proportion who entered their first partnership at marriage) for two age-cohorts of women. It is clear from these data that the younger women, those aged 25-29, were much more likely to have commenced their first partnership with cohabitation compared with the older women. There are marked increases to be seen in the proportions of women who cohabited in most countries, for example, in France 45 per cent of the older women but 79 per cent of the younger women cohabited; a pattern that is repeated across many of the nations. The main exceptions are Sweden and the Southern European countries. In Sweden cohabiting rather than marrying was already well established amongst the older women, and in Italy and Spain there are indications of a rise in cohabitation; but for the majority of women in these countries marriage still heralds the start of first partnership.

\section{Duration of cohabiting unions}

It appears that in many Western countries cohabitation has eclipsed marriage as the marker for entry into first union, but is there any evidence that cohabiting unions are becoming durable alternatives to marriage? To examine this issue we posed the question how long do first 
partnerships that commence with cohabitation last? This is not a question with a straightforward answer, as estimates of the duration of cohabiting unions need to take into account exit through marriage, exit through dissolution and for those unions that continue, censoring at the time of the interview. Life table analysis (single decrement) was used to estimate the extent to which cohabitations had converted into marriages or dissolved by a specified time from the start of the union. Table 1 provides two estimates for women aged 25-29 at the time of the survey: firstly the proportions of cohabiting unions expected to be dissolved by five years from the start of the union and secondly, the expected proportions of cohabiting unions that would have converted to marriages amongst those unions that had survived for five years. There is some variation in the propensity to marry across nations. Sweden exhibits the lowest conversion rate to marriage; only 1 in 3 of the cohabitations had become marriages within five years of the start of the partnership. In most other countries over 1 in 2 cohabitations had converted to marriages by the 5th anniversary of the union. Turning to the extent to which cohabiting unions dissolve we see that in most countries around 1 in 3 had dissolved by the 5th anniversary of the start of the union. The propensity for cohabiting unions to either convert to marriages or to dissolve is somewhat higher in the USA than in the European countries.

These analyses of the most recently available comparable data on union formation shows there to be marked variation in the ways men and women are forming partnerships across Western nations. In the 1990s, marriage was still the pre-eminent marker for entry into first union in the southern European countries whereas in most western and northern European countries and in the USA cohabitation has eclipsed marriage as the marker for first partnership. Across all these nations, after five years, only a minority of cohabiting unions remain intact, they have either converted into marriages or dissolved. Sweden was the only country where there was evidence of longer-term cohabitation.

Our analyses have also shown that cohabitation tends to be a short-lived affair in many countries, but this may well be changing. These data relate in the main to behaviour of cohorts forming partnerships in the early 1990s and since then there have been further increases in the level and duration of cohabitation (Haskey, 2001; Noack, 2001). 


\begin{tabular}{|c|c|c|}
\hline Country & $\begin{array}{l}\text { Proportions dissolved } \\
\text { by } 5 \text { years }(\%)\end{array}$ & $\begin{array}{c}\text { Surviving unions that had } \\
\text { converted to marriages by } \\
5 \text { years }(\%)\end{array}$ \\
\hline Sweden & 37 & 34 \\
\hline Norway & 35 & 56 \\
\hline Finland & 31 & 60 \\
\hline Austria & 26 & 54 \\
\hline Switzerland & 38 & 67 \\
\hline West Germany & 36 & 57 \\
\hline France & 31 & 63 \\
\hline Great Britain & 36 & 58 \\
\hline USA & 47 & 82 \\
\hline
\end{tabular}

Author's analysis of FFS data and BHPS

\section{The rise of non-marital childbearing}

Alongside the rise in cohabitation there have been striking increases in the levels of non-marital childbearing, two developments that are not unrelated. It is clear from Figure 3 that in recent decades there have been marked increases in the proportions of births occurring outside of legal marriage, but there also continues to be variation in the extent of nonmarital childbearing across nations. As we see in Figure 4 at one extreme are the Nordic countries where well over 40 per cent of births in 1999 were outside marriage and at the other extreme are the southern European countries of Italy and Greece where, along with Switzerland, 10 per cent or fewer births occurred outside marriage. Between these two extremes two broad groupings can be discerned. A set of countries with ratios between 15 and 25 per cent including the geographically close Benelux countries, West Germany and Portugal, and a set with 30 per cent or more which includes Ireland, the United Kingdom, Austria, Finland and France and the USA. 
Figure 3: Non marital births per 100 live births

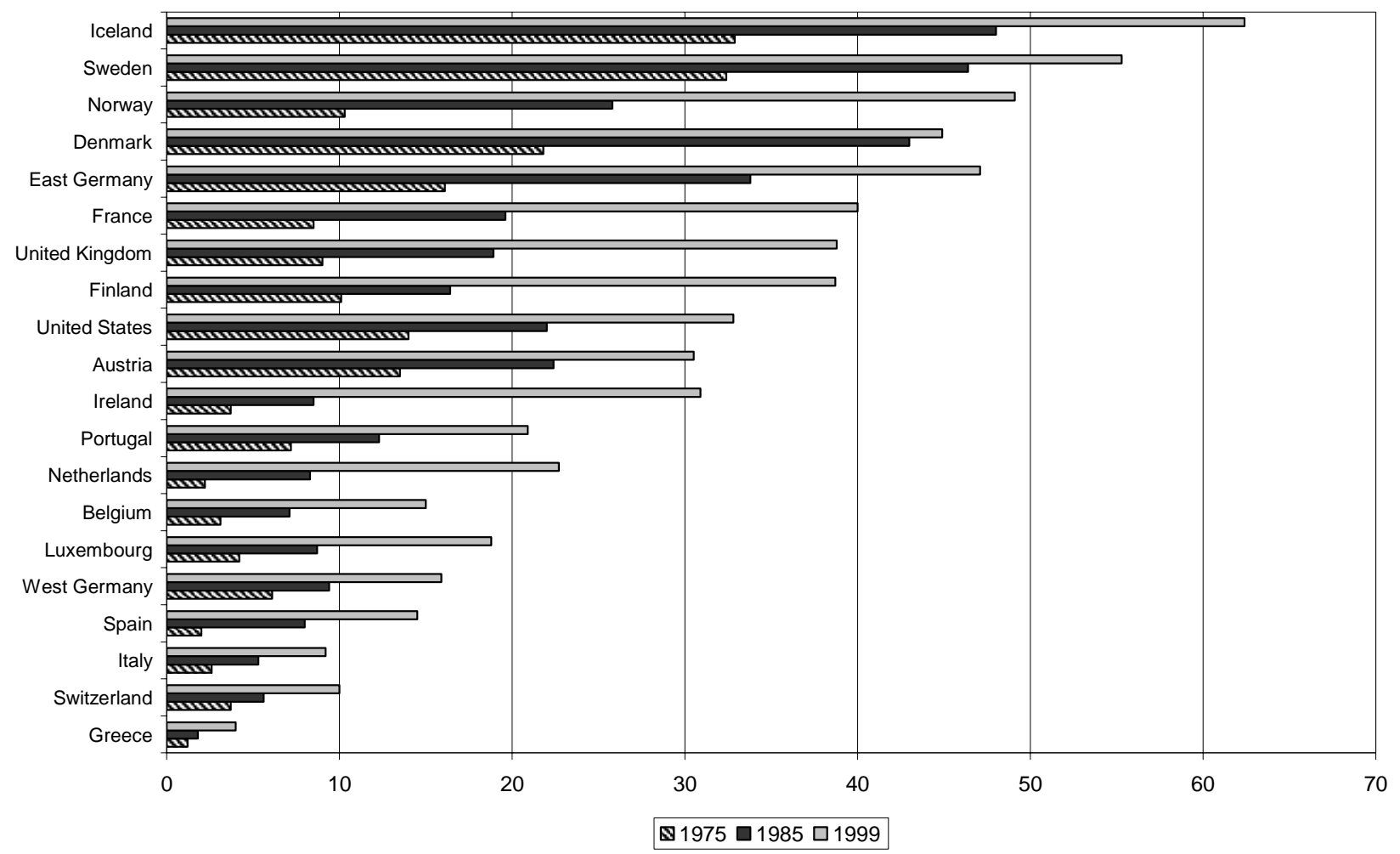

Undoubtedly, an important factor driving the rise in non-marital childbearing is the rise in cohabitation that has occurred, particularly since the beginning of the 1980s in many countries. However, as we saw above there is a good deal of diversity across nations in the levels of cohabitation. In Europe levels of cohabitation and childbearing outside marriage tend to be in accord, with countries with high levels of cohabitation having higher rates of non-marital childbearing and vice versa. However, there are exceptions. Britain, Ireland (and the USA) appear to have higher levels of childbearing outside marriage than one would expect from cohabitation estimates alone, and the Netherlands, West Germany and Switzerland have lower rates of non-marital childbearing than might be anticipated from their levels of cohabitation. This suggests that norms about marriage being the conventional setting for having children may well be stronger in some countries than others.

\section{Partnership context of first birth}

The union and fertility histories collected in FFS surveys allowed us to examine the partnership context of first birth in more detail. Table 2 shows the proportions of women in the various countries who made the 
transition to motherhood in one of four settings: before they had any coresidential partnership; within their first partnership which was a cohabitation; within first marriage; and after their first partnership (either a cohabitation or a marriage).

There are a number of findings that stand out. It is the case that in almost all these countries it is normative to become a mother in the first partnership. There are signs of change in Sweden with post-firstpartnership parenthood increasing from 12 to 19 per cent over the two age cohorts. Having a child prior to a partnership is a minor practice in many countries including countries with high levels of non-marital childbearing and countries with low levels (Table 2). For example, the overall proportion of women who had a child prior to any union was only 7 per cent in Sweden and 6 per cent in France. The extent of out of partnership births is somewhat higher in Norway and notably higher in Austria, but Austria has a long history of marriage following on from a first birth (Prinz, 1995). A simple comparison of the partnership context of first birth for the two age cohorts aged 25-29 and 35-39 shows that in most countries the proportions of births occurring prior to a first partnership have hardly changed over recent cohorts. Intriguingly, this is less the case in Great Britain and the USA where the proportions of first births occurring to solo mothers have increased. In Spain and Italy and to a lesser extent Switzerland first marriage continues to be the preeminent context for first births whereas, in the remaining countries the picture is less clear-cut. Nevertheless, across most of the countries there is a discernible movement away from having a child within marriage to having a child within a cohabiting union. 


\section{Table 2: Percentage of women with different partnership contexts at first birth according to age of woman}

\begin{tabular}{|c|c|c|c|c|c|}
\hline Country & $\begin{array}{l}\text { Before any } \\
\text { partnership }\end{array}$ & $\begin{array}{c}\text { In first } \\
\text { cohabiting union }\end{array}$ & $\begin{array}{c}\text { In first } \\
\text { marriage }\end{array}$ & $\begin{array}{c}\text { After first } \\
\text { partnership ended }\end{array}$ & $\begin{array}{c}\text { \% with first birth } \\
\text { by survey }\end{array}$ \\
\hline \multicolumn{6}{|c|}{ Norway** } \\
\hline $25-29$ & 12 & 28 & 53 & 8 & 68 \\
\hline $35-39$ & 13 & 7 & 75 & 4 & 91 \\
\hline $20-45$ & 12 & 18 & 65 & 5 & 62 \\
\hline \multicolumn{6}{|c|}{ Sweden ${ }^{* *}$} \\
\hline 25-29 & 6 & 53 & 23 & 19 & 66 \\
\hline $35-39$ & 6 & 53 & 30 & 12 & 92 \\
\hline $20-45$ & 7 & 51 & 29 & 13 & 74 \\
\hline \multicolumn{6}{|l|}{ Austria } \\
\hline 25-29 & 21 & 29 & 47 & 3 & 70 \\
\hline $35-39$ & 20 & 20 & 53 & 7 & 91 \\
\hline $20-45$ & 20 & 22 & 53 & 5 & 73 \\
\hline \multicolumn{6}{|c|}{ Switzerland } \\
\hline 25-29 & 4 & 8 & 78 & 10 & 45 \\
\hline $35-39$ & 5 & 8 & 76 & 11 & 83 \\
\hline 20-45 & 5 & 7 & 77 & 11 & 66 \\
\hline \multicolumn{6}{|c|}{ West Germany } \\
\hline 25-29 & 11 & 17 & 64 & 8 & 38 \\
\hline $35-39$ & 11 & 8 & 73 & 8 & 75 \\
\hline $20-39$ & 10 & 13 & 70 & 7 & 45 \\
\hline \multicolumn{6}{|l|}{ France } \\
\hline $25-29$ & 9 & 22 & 62 & 7 & 56 \\
\hline $35-39$ & 5 & 11 & 80 & 4 & 91 \\
\hline $20-45$ & 6 & 14 & 74 & 6 & 71 \\
\hline \multicolumn{6}{|c|}{ Great Britain } \\
\hline $25-29$ & 15 & 17 & 59 & 8 & 54 \\
\hline $35-39$ & 4 & 4 & 82 & 9 & 80 \\
\hline $20-45$ & 9 & 9 & 75 & 8 & 65 \\
\hline \multicolumn{6}{|l|}{ USA } \\
\hline $25-29$ & 20 & 15 & 54 & 11 & 70 \\
\hline $35-39$ & 14 & 8 & 66 & 12 & 86 \\
\hline $20-45$ & 17 & 11 & 60 & 12 & 80 \\
\hline \multicolumn{6}{|l|}{ Italy } \\
\hline $25-29$ & 4 & 5 & 90 & 1 & 36 \\
\hline $35-39$ & 5 & 3 & 90 & 1 & 83 \\
\hline $20-45$ & 5 & 3 & 90 & 1 & 61 \\
\hline \multicolumn{6}{|l|}{ Spain } \\
\hline $25-29$ & 8 & 6 & 85 & - & 47 \\
\hline $35-39$ & 4 & 3 & 92 & 1 & 92 \\
\hline $20-45$ & 5 & 3 & 90 & 1 & 65 \\
\hline
\end{tabular}

Author's analysis of FFS data and BHPS. **Sweden 1954 and 1964 cohorts: 35-39 and 25-29 equivalent. Norway 1950 and 1960 cohorts: 35-39 and 25-29 equivalent. 


\section{Parental separation and context of first birth}

Children born to a solo mother are likely to be living in more impoverished circumstances than children born into a couple-family, but does it matter whether a child is born within a cohabiting union or marital union. On a day-to-day basis from a child's perspective there may be little to distinguish between the two types of unions. But what about the probability of their parent's union remaining intact. We enquired whether children born into cohabiting unions as compared with those born to married parents were more or less likely to see the separation of their parents, and whether parental marriage after their birth made any difference? We used life table analysis to estimate the survival probabilities of partnerships where the clock started with the birth of the child rather than the onset of the union. Life tables were estimated for women who had a marital birth and amongst those who had a non-marital birth, marriage was included as a time varying covariate. Figure 4 shows the proportions of unions surviving 5 years after the birth of their first child for all marital unions and for the two subsets of cohabiting unions, those that had converted into marriages by the time of the survey and those that had not.

In all the countries included in our analysis children born within marriage were less likely to see their parents separate than those born in a cohabiting union (not shown). Within the set of cohabiting unions those that had not been converted into marriages were the most fragile, with at least 1 in 5 of these unions having dissolved by the time the child was 5 years old. Amongst children born within marriage or cohabiting unions that subsequently converted to marriages there was little difference in the chances of them seeing the break-up of their parents' marriage by their 5th birthday in Sweden, Norway, Austria and West Germany; with less than 1 in 10 of these children having experienced parental separation. However, in France and Switzerland and the USA and most noticeably in Great Britain children born into marital unions were more likely to see their parents remain together until their 5th birthday than those children born into a cohabiting union that converted into a marriage. In Italy and Spain the numbers of dissolutions occurring to converted unions were too small for reliable estimates to be made. 
Figure 4: Life table estimates of percentage of unions surviving 5 years after the birth of the first child amongst women aged 20-45 according to partnership context

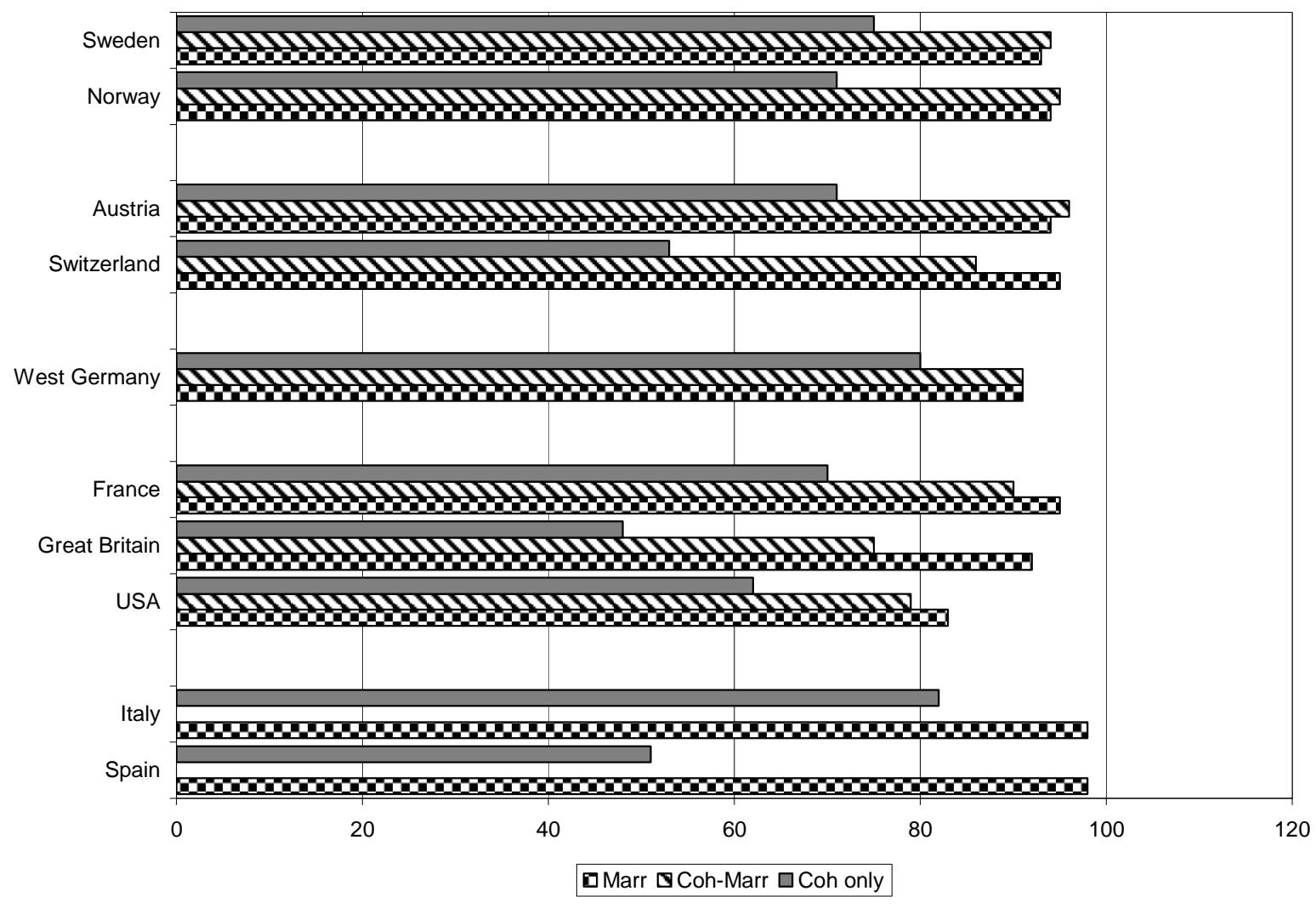

\section{Parental divorce and children's partnership and parenthood behaviour}

There is evidence as we mentioned in the introduction for the USA and Great Britain that children who experience parental divorce are more likely to form partnerships and become parents at an early age, to cohabit and have children outside of marriage. Here we enquire whether this is the case in other nations and we present our analyses for women (the patterns for men were broadly similar). The UN ECE Fertility and Family Surveys included a question on whether the parents of the respondents had ever separated or divorced and the age at which this happened. Table 3 shows the average ages at first partnership and average age at becoming a mother for women who had and had not experienced parental separation by age 16. Table 4 shows for the two groups of women the proportions of first unions that were direct marriages and the proportions of women who had their first child 
within a first partnership that was a marriage. It is clear that across all the nations women who experience parental divorce: are more likely to form partnerships and become parents at an earlier age; their first union is less likely to be a marriage than a cohabitation; and they are less likely to have a child within marriage than their peers without such an experience. These behaviours are of course not necessarily independent. Early partnership is a proximate determinant for early parenthood and cohabitation is a proximate determinant of having a child outside of marriage.

\section{Table 3: Average age at first partnership and average age at first child according to whether women had experienced parental separation during childhood amongst women aged between 20 and 39 years}

\begin{tabular}{|c|c|c|c|c|c|}
\hline \multirow[t]{2}{*}{ Country } & \multicolumn{2}{|c|}{$\begin{array}{l}\text { Average age at first } \\
\text { partnership (in years) }\end{array}$} & \multicolumn{2}{|c|}{$\begin{array}{l}\text { Average age at first birth } \\
\text { (in years) }\end{array}$} & \multirow{2}{*}{$\begin{array}{c}\text { Percent with } \\
\text { parental separation } \\
\text { 0-16 years } \\
\text { Percentage }\end{array}$} \\
\hline & $\begin{array}{l}\text { Parental } \\
\text { separation }\end{array}$ & $\begin{array}{l}\text { No Parental } \\
\text { Separation }\end{array}$ & $\begin{array}{c}\text { Parental } \\
\text { separation }\end{array}$ & $\begin{array}{l}\text { No Parental } \\
\text { Separation }\end{array}$ & \\
\hline Norway & - & - & - & - & \\
\hline Sweden & 20.07 & 20.97 & 22.74 & 24.09 & 14 \\
\hline Austria & 19.81 & 21.02 & 22.14 & 22.86 & 13 \\
\hline Switzerland & 21.43 & 22.40 & 24.83 & 25.52 & 14 \\
\hline West Germany & 20.83 & 21.73 & 23.06 & 24.15 & 14 \\
\hline France & 20.78 & 21.04 & 22.2 & 23.13 & 15 \\
\hline Great Britain & 20.68 & 21.32 & 21.69 & 23.32 & 17 \\
\hline USA & 20.10 & 21.25 & 21.38 & 22.74 & 30 \\
\hline Italy & 21.4 & 22.69 & 23.71 & 24.18 & 6 \\
\hline Spain & 21.28 & 22.25 & 22.84 & 23.76 & 4 \\
\hline
\end{tabular}

Norway did not collect information on parental separation. Author's analysis of FFS data and for GB the National Survey of Sexual Attitudes and Lifestyles, 1991. 
Table 4: Percentage of women who married directly and percentage of women who had a marital first birth according to whether women had experienced parental separation during childhood amongst women aged between 20 and 39 years

\begin{tabular}{lcccc}
\hline \hline Country & \multicolumn{2}{c}{ Direct Marriage } & \multicolumn{2}{c}{ Marital first birth } \\
& $\begin{array}{c}\text { Parental } \\
\text { separation }\end{array}$ & $\begin{array}{c}\text { No Parental } \\
\text { Separation }\end{array}$ & $\begin{array}{c}\text { Parental } \\
\text { separation }\end{array}$ & $\begin{array}{c}\text { No Parental } \\
\text { Separation }\end{array}$ \\
\hline Norway & - & - & - & - \\
Sweden & 3 & 7 & 21 & 30 \\
Austria & 8 & 25 & 41 & 56 \\
Switzerland & 16 & 24 & 63 & 80 \\
West Germany & 17 & 26 & 54 & 72 \\
France & 20 & 37 & 35 & 60 \\
Great Britain & - & - & - & - \\
USA & 26 & 43 & 51 & 63 \\
Italy & 65 & 88 & 77 & 91 \\
Spain & 67 & 86 & 73 & 91 \\
\hline \hline
\end{tabular}

Author's analysis of FFS data. Norway did not collect information on parental separation. GB the National Survey of Sexual Attitudes and Lifestyles did not distinguish between first partnerships that were marriages and those that were cohabitations.

It is noteworthy that the findings are so robust across nations with quite different cultures and welfare regimes. The findings with respect to cohabitation and childbearing outside marriage apply in northern, western and southern European countries, as well as the USA, and in countries where marrying directly is rare and cohabitation normative as in Sweden and in countries where marrying directly is normative and cohabitation is relatively rare such as Italy. It is not clear why children who experienced parental divorce tend to cohabit but we provide some observations and speculations in the concluding section of this paper.

\section{Parental divorce, and partnership dissolution}

A number of studies using data from the USA and Great Britain have shown experience of parental divorce to be associated with an increased risk of marital breakdown in the child's own marriage (Mueller and 
Pope, 1977; Glenn and Kramer, 1987; Kiernan, 1986; McLanahan and Bumpass 1988; Kiernan and Cherlin, 1999). Here we assess the extent to which partnership breakdown is more common amongst children who have experienced parental separation for the set of FFS countries included in our analysis.

Table 5: Relative risks of partnership dissolution according to experience of parental divorce and amongst women aged 20 to 39 years at the time of the survey. Relative risks derived from Cox proportional hazard models with marriage included as a time varying co-variate. Model 1 no controls Model 2 controls for type of first partnership and age at first partnership

\begin{tabular}{lcc}
\hline Country & No controls & $\begin{array}{c}\text { Controls for age and } \\
\text { type of first } \\
\text { partnership }\end{array}$ \\
\hline Sweden & $1.55^{* * *}$ & $1.38^{* * *}$ \\
Austria & $2.16^{* * *}$ & $1.88^{* * *}$ \\
Switzerland & $1.92^{* * *}$ & $1.62^{* * *}$ \\
West Germany & $2.03^{* * *}$ & $1.74^{* * *}$ \\
France & $1.45^{* * *}$ & 1.03 \\
USA & $1.44^{* * *}$ & $1.18^{* * *}$ \\
\hline \hline
\end{tabular}

Author's analysis of FFS data. Norway did not collect information on parental separation. No information available for GB as BHPS did not have a question on parental divorce, and the National Survey of Sexual Attitudes and Lifestyles did not have a partnership history. Italy and Spain numbers too small for reliable analysis. ${ }^{* * *} \mathrm{p}<0.0001{ }^{* *} \mathrm{p}<0.01 * \mathrm{p}<.0 .05$

The risk of partnership dissolution is known to be associated with age at first partnership and there is evidence for some countries that unions that commence with cohabitation are more fragile than those that commence with marriage. Moreover we have shown that children who experience parental separation during childhood tend to have a younger age at first partnership and a tendency to cohabit more than those brought up with both their parents. We control for these factors in our analysis. The first column in Table 5 shows the gross risk of partnership breakdown according to whether or not the woman had experienced parental divorce for countries with relevant information and with numbers sufficient for analysis. The second column shows the relative risk of partnership breakdown taking into account type and age at first 
partnership. From this table we see that in these countries (with the exception of France) children who experienced parental divorce during childhood were significantly more likely to experience partnership breakdown in adulthood compared with those without such an experience.

Our analysis has shown for a number of countries with differing levels of divorce that adult children who experienced a parental separation during childhood have a heightened risk of seeing their own partnerships dissolve. There are also strong associations between age and type of first partnership with the estimated effects of parental separation being reduced when the demographic variables were taken into account. This suggests that cohabitation and early partnership may be important, but not necessarily exclusive pathways through which parental separation or the unmeasured characteristics correlated with it, affect partnership dissolution in adulthood.

\section{Longitudinal analysis of parental separation}

Our foregoing analysis for a range of Western nations on the partnership and parenthood behaviour of children who experienced parental separation during childhood has produced a number of robust findings. Children who experience parental divorce compared with those who did not are more likely to form partnerships and become parents at a young age; they are more likely to opt for cohabitation over marriage as their preferred form of first union; and they are less likely to have their first child within marriage. They are also more likely to experience partnership dissolution.

Analysis of these surveys have provided an invaluable cross-national perspective on the robustness of findings across different cultures and welfare regimes but such surveys are unable to provide insights as to what mechanisms might lay behind these findings, for which prospective longitudinal information is a prerequisite. Here, we make use of a national longitudinal study of a British birth cohort of children born in 1970 and followed up since birth to the present time (Bynner et al, 1997 and 2000). Information has been collected around the time of the birth, and during childhood at ages 5, 10, 16 and in adulthood at ages 26 (a short postal survey) and at age 30 (in 2000) when a comprehensive interview was carried out. These young people have just passed through 
their prime family formation ages and were amongst the first generation to have passed through childhood during a period of high divorce rates.

One of the difficult challenges in assessing the legacy of parental separation is being able to sort out the conditions that lead couples to separate and the potential effects on children, from the consequences of the dissolution itself. It is known that partnership dissolution is more likely to occur among couples with personal, social, economic and health problems (White, 1990; Kiernan and Mueller, 1999). As a consequence the non-random nature of this population suggests that the effects of factors that existed prior to the separation, for example poverty or depression, might be confused with its consequences.

To begin to address this challenge we pursue a number of questions.

$>\quad$ Firstly, we assess the extent to which parental separation during different periods of childhood have longer-term consequences for the partnership formation and dissolution and parenthood behaviour in adulthood.

$>$ Secondly, we assess whether the legacy for those young people whose parents do not separate until they are in their late teens and twenties differs from those whose parents separated during childhood.

$>$ Thirdly, we assess whether the associations that we find are attenuated when we take into account child and family characteristics prior to the parent's separation.

\section{Timing of parental separation and partnership and parenthood behaviour}

When the cohort was interviewed at age 30, 28 per cent $(\mathrm{N}=9997)$ reported that their parents had separated and gave an age at separation. We divided the sample into 5 groups according to age at separation: those whose parents separated prior to age $5(n=808)$; those where it occurred when the children were aged 6-10 years $(n=578)$ and 11-16 years $(n=703)$; and two older groups, 17-21 $(n=387)$ and 22-30 $(n=324)$ years. Twenty one per cent of the cohort had experienced parental separation by age 16, and a further 7 per cent had had such an experience by age 30 . 
Tables 6 and 7, for women and men respectively, provide summary information on partnership and parenthood behaviour according to age at parental separation.

Table 6: Partnership and Parenthood Behaviour according to age at parental separation - Women

\begin{tabular}{|c|c|c|c|c|c|c|c|}
\hline & $\begin{array}{c}\text { No } \\
\text { Parental } \\
\text { Separation }\end{array}$ & $\begin{array}{c}\text { Parental } \\
\text { Separation } \\
0-5 \text { years }\end{array}$ & $\begin{array}{c}6-10 \\
\text { years }\end{array}$ & $\begin{array}{l}11-16 \\
\text { years }\end{array}$ & $\begin{array}{l}17-21 \\
\text { years }\end{array}$ & $\begin{array}{l}22-30 \\
\text { years }\end{array}$ & Total \\
\hline$\%$ ever married & 55 & 44 & 43 & 43 & 42 & 44 & 52 \\
\hline $\begin{array}{l}\% \text { ever } \\
\text { partnered }\end{array}$ & 92 & 92 & 89 & 92 & 91 & 88 & 91 \\
\hline $\begin{array}{l}\% \text { married } \\
\text { directly }\end{array}$ & 20 & 11 & 6 & 5 & 8 & 12 & 17 \\
\hline $\begin{array}{l}\text { Average age at } \\
\text { first } \\
\text { partnership }\end{array}$ & 22.3 & 21.1 & 20.8 & 21.1 & 21.8 & 21.9 & 22.0 \\
\hline$\%$ ever mother & 55 & 66 & 61 & 66 & 56 & 53 & 57 \\
\hline $\begin{array}{l}\% \text { teenage } \\
\text { mothers }\end{array}$ & 16 & 29 & 29 & 30 & 15 & 17 & 19 \\
\hline $\begin{array}{l}\text { Average age at } \\
\text { first birth }\end{array}$ & 23.8 & 22.5 & 22.5 & 22.3 & 23.9 & 23.9 & 23.5 \\
\hline $\begin{array}{l}\% \text { first birth } \\
\text { outside a union }\end{array}$ & 18 & 27 & 24 & 29 & 25 & 18 & 20 \\
\hline $\begin{array}{l}\% \text { first birth } \\
\text { marital }\end{array}$ & 58 & 36 & 42 & 36 & 42 & 51 & 53 \\
\hline $\begin{array}{l}\text { \% first } \\
\text { partnership } \\
\text { ended }\end{array}$ & 32 & 48 & 44 & 43 & 45 & 43 & 35 \\
\hline
\end{tabular}

Author's analysis of Birth Cohort 70 data 
Table 7: Partnership and Parenthood Behaviour according to age at parental separation - Men

\begin{tabular}{|c|c|c|c|c|c|c|c|}
\hline & $\begin{array}{c}\text { No } \\
\text { Parental } \\
\text { Separation }\end{array}$ & $\begin{array}{l}\text { Parental } \\
\text { Separation } \\
0-5 \text { years }\end{array}$ & $\begin{array}{c}\text { 6-10 } \\
\text { years }\end{array}$ & $\begin{array}{l}11-16 \\
\text { years }\end{array}$ & $\begin{array}{l}17-21 \\
\text { years }\end{array}$ & $\begin{array}{l}22-30 \\
\text { years }\end{array}$ & Total \\
\hline $\begin{array}{l}\% \text { ever } \\
\text { married }\end{array}$ & 45 & 32 & 40 & 38 & 36 & 31 & 43 \\
\hline $\begin{array}{l}\% \text { ever } \\
\text { partnered }\end{array}$ & 87 & 86 & 83 & 85 & 86 & 75 & 86 \\
\hline $\begin{array}{l}\text { \% married } \\
\text { directly }\end{array}$ & 14 & 5 & 9 & 10 & 7 & 8 & 13 \\
\hline $\begin{array}{l}\text { Average age at } \\
\text { first } \\
\text { partnership }\end{array}$ & 23.5 & 22.5 & 22.3 & 22.7 & 22.9 & 23.3 & 23.2 \\
\hline$\%$ ever father & 42 & 54 & 48 & 47 & 38 & 38 & 43 \\
\hline $\begin{array}{l}\% \text { young } \\
\text { fathers (age } 21 \\
\text { and younger) }\end{array}$ & 14 & 28 & 24 & 23 & 25 & 10 & 17 \\
\hline $\begin{array}{l}\text { Average age at } \\
\text { first birth }\end{array}$ & 25.1 & 23.9 & 24.2 & 24.2 & 24.1 & 25.2 & 24.8 \\
\hline $\begin{array}{l}\text { \% first birth } \\
\text { outside a } \\
\text { union }\end{array}$ & 12 & 22 & 22 & 25 & 17 & 15 & 15 \\
\hline $\begin{array}{l}\% \text { first birth } \\
\text { marital }\end{array}$ & 58 & 30 & 42 & 38 & 42 & 51 & 52 \\
\hline $\begin{array}{l}\text { \% first } \\
\text { partnership } \\
\text { ended }\end{array}$ & 29 & 46 & 44 & 45 & 42 & 44 & 33 \\
\hline
\end{tabular}

Author's analysis of Birth Cohort 70 data

The highlights are as follows.

Marriage was less common amongst men and women who have experienced the separation of their parents but they were no less likely to have had a partnership. There is little evidence that the timing of separation affects this association, with the exception of men who experienced parental separation after age 21 , who have a lower probability of having formed a partnership. 
Men and women who experienced parental separation during childhood (regardless of the age at which it occurred) have a younger average age at first partnership than those whose parents did not separate, and those who experienced parental separation post-childhood tend to have a later age at first partnership.

$>\quad$ Marrying directly was a minority practice amongst this cohort but the proportion was higher amongst those who had not experienced a parental separation and lower amongst those whose parents had separated, with no distinctive pattern according to age at parental separation.

By age 30, 57 per cent of the women and 43 per cent of the men had had a first child. Men and women who had experienced parental separation under age 17 were more likely to be parents than their peers whose parents separated at older ages, who had similar parenthood probabilities to their peers whose parents had not separated.

$>$ Young people who experience parental separation during childhood became parents on average one year younger than those without this experience. The average age at first birth was similar for those who experienced parental separation during early, mid and later childhood. Women whose parents separated after childhood were similar to women whose parents had not separated but men whose parents separated when they were aged 17-21 had an age pattern of parenthood that was similar to their peers who had experienced parental separation during childhood. Why this should occur amongst men and not women is intriguing. It may be that men are more vulnerable than women to parental separation at these ages, perhaps related to their later age at maturation. Becoming a teenage mother is almost twice as common amongst women who experienced parental divorce during childhood compared with their peers whose parents had not separated or who separated in later life.

Around 1 in 4 of the men and women who had become parents and whose parents had separated during their childhood had had their first child outside of a union (i.e. the mother and father were not living together when the child was born). Having a child within marriage was notably higher amongst those whose parents had not separated and to a lesser extent amongst those whose parents separated after they were age 21 . 
> Partnership dissolution was substantially higher and similar amongst men and women who experienced parental separation regardless of whether this was in childhood or adulthood.

This analysis based on the experiences of a recent cohort of British young people has generally confirmed our international findings. The additional element that we examined for the cohort was the timing of parental separation in relation to the partnership and parenthood behaviour of their children. Our analyses showed that whether parental separation occurs during early, middle or later childhood seemingly does not lead to different patterns of partnership and parenthood behaviour in adulthood. It is the fact of parental separation that seems to matter rather than the timing of the separation in the life course of the child.

The story with respect to post-childhood parental separation was more mixed. Comparisons with their contemporaries who experienced parental separation during childhood showed that in the partnership domain the post-childhood set had broadly similar probabilities to them of ever having married, of marrying directly and of partnership dissolution. However, the post-childhood separation set, particularly the women, tended to have an older at first partnership. The post-childhood set were also less likely to have become parents, and those who experienced parental separation after they were age 21 tended to have become parents at an older age and were more likely to have a marital birth compared with their peers who experienced parental separation during childhood.

\section{Pre-separation attributes}

We now come to our third question as to whether the associations that we find between parental separation and the partnership and parenthood behaviour of their children attenuate when we take into account child and family characteristics prior to the parent's separation.

\section{The precursors}

The earliest interview from which we have detailed information on the child and their family is the one carried out at age 5 . The birth survey was primarily concerned with obstetric details. The potential explanatory factors we chose to examine come from three domains: the 
cognitive, psychological and socio-economic. For the child we used their scores on the English Picture Vocabulary Test (EPVT), which is an adaptation of the American Peabody Picture Vocabulary Test. (Butler et al 1970). We divided the distribution up into quintiles. We also included some features of the child's personality and behaviour. The mother's of the cohort members completed the inventory devised by Rutter and colleagues (Rutter, Tizard and Whitmore, 1970). From the responses three components were distinguished: an anxiety, aggression and a restlessness component (after Hobcraft, 1998). In our analysis we had a simple split into low, medium and high and missing was also included. We also included a measure of the mother's mental well-being based on her score on the Malaise Inventory (Rutter, Tizard and Whitmore, 1970). This is a 24 item-check list of symptoms such as anxiety, irritability, depressed mood, and psychosomatic illness. Scores of 7 or more have been used in previous studies as indicative of those with a high risk of depression (Rutter, Tizard and Graham, 1976; Richman, 1978) and we followed this convention. Unfortunately no income data was collected prior to the age 10 interviews so as a guide to socio-economic status we used an indicator of father's social status derived from his socioeconomic group. These data were also collected at the birth interview, which we used in preference to the age 5 data as it captured more fathers prior to separation. We collapsed the variable into four levels: non-manual father, manual father, other (in the main unemployed) and no father figure.

Table 8 provides a guide to the extent of the association between these precursors and age at parental separation. It shows the odds ratios for age at parental separation according to whether the child: was in the lowest quintile of the EPVT; had high anxiety, aggression and restlessness scores; whether the mother had a high malaise score; and whether their father had a manual occupation. For the child's personality-behavioural measures we show the odds ratios separately for boys and girls as they differed in their scores on these measures. There is evidence from this table that children who were subsequently to experience a parental separation differed from their contemporaries who did not, even before the separation. For example, children who experienced a parental separation after age 5 tended to have lower scores on the EPVT, they were more likely to have a manual father, and their mother was more likely to be depressed. This latter finding applied to both childhood and post-childhood divorce. Girls who subsequently 
experienced a parental separation tended to be more anxious, and the analogous group of boys tended to be more aggressive and restless.

Table 8: Association between childhood control variables and age at parental separation: Odds ratios

\begin{tabular}{|c|c|c|c|}
\hline Men and Women & $\begin{array}{l}\text { Lowest Quintile } \\
\text { on EPVT at age } 5\end{array}$ & $\begin{array}{l}\text { Mother with high } \\
\text { malaise score } \\
\text { when child age } 5\end{array}$ & $\begin{array}{l}\text { Manual Father at } \\
\text { birth }\end{array}$ \\
\hline No separation & 1 & 1 & 1 \\
\hline $0-5$ & $1.56^{* * *}$ & $1.99^{* *}$ & $1.48^{* * *}$ \\
\hline $6-10$ & $1.30^{*}$ & $1.81^{* * *}$ & $1.31^{* *}$ \\
\hline $11-16$ & $1.34^{* *}$ & $1.51^{* * *}$ & $1.30^{* *}$ \\
\hline $17-21$ & 1.14 & $1.44^{* *}$ & 1.07 \\
\hline $22-30$ & 0.82 & $1.31+$ & 1.04 \\
\hline Men & $\begin{array}{l}\text { High Anxiety } \\
\text { Score }\end{array}$ & $\begin{array}{l}\text { High Aggression } \\
\text { Score }\end{array}$ & $\begin{array}{l}\text { High Restlessness } \\
\text { Score }\end{array}$ \\
\hline No separation & 1 & 1 & 1 \\
\hline $0-5$ & 1.08 & $1.66^{* *}$ & $1.28+$ \\
\hline $6-10$ & 1.04 & $1.37^{*}$ & $1.31+$ \\
\hline $11-16$ & 1.01 & $1.77^{* *}$ & $1.47^{* *}$ \\
\hline $17-21$ & $1.39+$ & 1.23 & 1.24 \\
\hline $22-30$ & $1.66^{* *}$ & $1.54^{*}$ & $1.40+$ \\
\hline Women & $\begin{array}{l}\text { High Anxiety } \\
\text { Score }\end{array}$ & $\begin{array}{l}\text { High Aggression } \\
\text { Score }\end{array}$ & $\begin{array}{l}\text { High Restlessness } \\
\text { Score }\end{array}$ \\
\hline No separation & 1 & 1 & 1 \\
\hline $0-5$ & $1.49^{* * *}$ & $2.31^{* * *}$ & $1.68^{* * *}$ \\
\hline $6-10$ & $1.37^{*}$ & 1.20 & 1.24 \\
\hline $11-16$ & $1.28^{*}$ & $1.65^{* *}$ & 1.05 \\
\hline $17-21$ & 0.93 & 1.33 & $1.66^{* * *}$ \\
\hline $22-30$ & 1.23 & 1.12 & $1.43+$ \\
\hline
\end{tabular}

Author's analysis of Birth Cohort 70 data ${ }^{* * *} \mathrm{p}<0.0001{ }^{* *} \mathrm{p}<0.01{ }^{*} \mathrm{p}<.0 .05+\mathrm{p}<0.10$

These factors were also associated (but not exclusively) with our outcome measures. For the women we looked at three parenthood outcomes, which we think have important implications for the wellbeing of mothers and their children. These were: becoming a teenage 
mother; becoming a solo mother (having a baby outside a co-residential partnership); and becoming a lone mother after the birth of the child. We also examined two partnership outcomes namely: whether the first partnership commenced with cohabitation or marriage and whether or not the first partnership had ended. For the men we examined three outcomes: becoming a young father (at age 21 or younger); whether the first partnership was a cohabitation or not; and whether their first partnership had ended.

Amongst the women reading scores were strongly associated with the parenthood outcomes but not the partnership outcomes. Aggression scores were associated with all the parenthood and partnership outcomes, and restlessness only with the partnership outcomes. Social status of the father was associated with all the outcomes and mothers malaise score with the parenthood outcomes but not the partnership outcomes. Amongst the men, reading scores, level of restlessness and aggression, mothers malaise score and social status were associated with becoming a young father and all these factors with the exception of reading scores were associated with partnership dissolution. None of the factors were implicated in the propensity to cohabit.

\section{Parental separation: youthful parenthood, solo motherhood and lone parenthood}

Amongst those who were parents by the time of the survey age 30, 19 per cent of the women had become mothers in their teens and a similar proportion 18 per cent of the men had become fathers by age 21 . This is a cohort of young people that have been delaying childbearing such that only 57 per cent of the women and 43 per cent of the men had had a child by age 30 , and it may be that young people who have a child in the twenties are an increasingly select group. Table 9 shows the odds ratios for young parenthood according to timing of parental separation and the odds ratios adjusted for the age 5 and birth factors. We see that after taking into account background factors there is a reduction in the odds of becoming a young mother or father if parental separation occurred at under age 5, but here we cannot say whether it is selection or postseparation influences that are operating. Amongst the women whose parents separated between ages 6 and 16 there is little change in the odds suggesting that our basket of background factors do not account for the association between parental separation at these ages and 
becoming a teenage mother. There is stronger evidence that the background factors are operating in the case of young fatherhood. We performed some additional analyses not shown here which included measures of income at age 10 and whether the young people had any qualifications or not. Adding these factors to the model did not alter the general thrust of the finding that parental separation is significantly associated with becoming a young parent.

Table 9: Odds ratios for young parenthood according to age at parental separation and adjusted for childhood factors

\begin{tabular}{lll}
\hline \hline Outcome & Odds ratios & $\begin{array}{l}\text { Adjusted Odds ratios } \\
\text { - Childhood factors }\end{array}$ \\
\hline Teenage Mother & & \\
No separation & 1 & 1 \\
$0-5$ & $2.16^{* * *}$ & $1.7^{* *}$ \\
$6-10$ & $2.24^{* * *}$ & $2.23^{* * *}$ \\
$11-16$ & $2.27^{* * *}$ & $2.21^{* * *}$ \\
$17-21$ & 0.92 & 0.88 \\
$22-30$ & 1.1 & 1.46 \\
& & \\
Young father (age & 21 and under) & \\
No separation & 1 & 1 \\
$0-5$ & $2.45^{* * *}$ & $2.16^{* * *}$ \\
$6-10$ & $1.98^{* *}$ & $1.90^{* *}$ \\
$11-16$ & $1.91^{* *}$ & $1.49+$ \\
$17-21$ & $2.07^{* * *}$ & $1.80+$ \\
$22-30$ & 0.70 & 0.69 \\
\hline \hline
\end{tabular}

Author's analysis of Birth Cohort 70 data. ${ }^{* * *} \mathrm{p}<0.0001{ }^{* *} \mathrm{p}<0.01{ }^{*} \mathrm{p}<.0 .05+\mathrm{p}<0.10$

Teenage motherhood is an important determinant of solo motherhood and lone motherhood more generally. For example the odds of a teenage mother being a solo mother at age 30 were 8.5 times those of an older mother. Similarly the odds of a teenage mother experiencing lone parenthood were 4 times that of an older mother. As a consequence of the importance of the association between teenage motherhood and solo and lone motherhood we first entered a control for this prior to making any adjustment for the background factors. From Table 10 column 2 we see that a control for teenage motherhood substantially reduces the 
association between parental separation and solo motherhood in adulthood. It would appear that at least in the context of Britain solo motherhood is a youthful phenomenon.

Table 10: Odds ratios for solo and lone motherhood according to age at parental separation, adjusted for teenage motherhood and for childhood factors

\begin{tabular}{llll}
\hline Outcome & Odds ratios & $\begin{array}{l}\text { Adjusted Odds for } \\
\text { teenage motherhood }\end{array}$ & $\begin{array}{l}\text { Adjusted Odds for } \\
\text { childhood factors only }\end{array}$ \\
\hline Solo Mother & & & \\
No separation & 1 & 1 & 1 \\
$0-5$ & $1.71^{* * *}$ & 1.21 & 1.20 \\
$6-10$ & $1.51^{*}$ & 1.04 & $1.75^{*}$ \\
$11-16$ & $1.91^{* * *}$ & 1.38 & $1.95^{* *}$ \\
$17-21$ & $1.54+$ & $1.67+$ & $1.73+$ \\
$22-30$ & 1.05 & 0.93 & 1.24 \\
& & & \\
Lone Mother & & 1 & 1 \\
No separation & 1 & $2.32^{* * *}$ & $2.49^{* * *}$ \\
$0-5$ & $2.44^{* * *}$ & $1.60^{*}$ & $1.68^{*}$ \\
$6-10$ & $1.80^{* * *}$ & $2.06^{* * *}$ & $1.98^{* *}$ \\
$11-16$ & $2.32^{* * *}$ & $1.90^{*}$ & $1.91^{*}$ \\
$17-21$ & $1.57^{*}$ & 0.90 & 1.07 \\
$22-30$ & 1.04 & & \\
\hline \hline
\end{tabular}

Author's analysis of Birth Cohort 70 data.

${ }^{* * *} \mathrm{p}<0.0001{ }^{* *} \mathrm{p}<0.01{ }^{*} \mathrm{p}<.0 .05+\mathrm{p}<0.10$

The attenuation of the association between parental separation and lone parenthood after taking into account the propensity to become a teenage mother was less pronounced than that found for solo motherhood. The adjusted odds ratios, after the introduction of the background factors and teenage motherhood, suggest a continuing and substantial association between parental separation under age 5 and lone motherhood in adulthood. Amongst women whose parents separated in later childhood their odds of being a lone parent are much lower after taking into account the background factors and whether they had become a mother in their teens. There is fairly unambiguous evidence that where parental separation occurs after age 21 the odds of these men 
and women being young parents, and of women becoming solo or lone mothers are similar to those young people whose parents had not separated. The evidence is less clear-cut when parental separation occurs in the later teens and very early twenties.

\section{Parental separation and partnership outcomes}

Table 11 shows the odds of women and men commencing their first union with cohabitation as opposed to a marriage according to age at parental separation. In most instances it is clear that children who experience parental separation whether in childhood or in adulthood are more likely to cohabit, and our basket of background factors does not appear to be implicated in this association.

Table 11: Odds ratios for whether first partnership was a cohabitation according to age at parental separation and adjusted for childhood factors

\begin{tabular}{lll}
\hline \hline Outcome & Odds ratios & $\begin{array}{l}\text { Adjusted Odds - } \\
\text { Childhood factors }\end{array}$ \\
\hline $\begin{array}{l}\text { First Union Cohabitation } \\
\text { Women }\end{array}$ & \\
No separation & 1 & 1 \\
$0-5$ & $2.09 * * *$ & $1.74^{* *}$ \\
$6-10$ & $4.09^{* * *}$ & $4.18^{* * *}$ \\
$11-16$ & $4.66^{* * *}$ & $5.21^{* * *}$ \\
$17-21$ & $2.83^{* * *}$ & $2.57^{* *}$ \\
$22-30$ & $1.76^{*}$ & $2.04^{* *}$ \\
& & \\
Men & & 1 \\
No separation & 1 & $4.54^{* * *}$ \\
$0-5$ & $3.29^{* * *}$ & $2.04^{* *}$ \\
$6-10$ & $1.75^{*}$ & $1.45+$ \\
$11-16$ & $1.48^{*}$ & $2.49^{* *}$ \\
$17-21$ & $2.15^{* *}$ & 1.47 \\
$22-30$ & $1.63+$ & \\
\hline \hline
\end{tabular}

Author's analysis of Birth Cohort 70 data.

${ }^{* * *} \mathrm{p}<0.0001{ }^{* *} \mathrm{p}<0.01{ }^{*} \mathrm{p}<.0 .05+\mathrm{p}<0.10$ 
Table 12: Relative risks for whether first partnership dissolved according to age at parental separation, adjusted for childhood factors and adjusted for age and type of first partnership

\begin{tabular}{llll}
\hline Outcome & Relative Risks & $\begin{array}{l}\text { Adjusted Relative } \\
\text { Risks - Childhood } \\
\text { factors }\end{array}$ & $\begin{array}{l}\text { Adjusted Relative } \\
\text { Risks - Age and Type } \\
\text { of First Partnership }\end{array}$ \\
\hline $\begin{array}{l}\text { First partnership dissolved } \\
\text { Women }\end{array}$ & & \\
No separation & 1 & 1 & 1 \\
$0-5$ & $1.53^{* * *}$ & $1.55^{* * *}$ & $1.40^{* *}$ \\
$6-10$ & $1.39^{* *}$ & $1.42^{* *}$ & 1.20 \\
$11-16$ & $1.36^{* *}$ & $1.27^{*}$ & 1.08 \\
$17-21$ & $1.48^{* *}$ & $1.57^{* *}$ & $1.45^{* *}$ \\
$22-30$ & $1.49^{* *}$ & $1.41^{*}$ & $1.29+$ \\
& & & \\
Men & & & 1 \\
No separation & 1 & 1 & $1.26^{*}$ \\
$0-5$ & $1.57^{* * *}$ & $1.42^{* *}$ & $1.29^{*}$ \\
$6-10$ & $1.39^{* *}$ & $1.44^{* *}$ & $1.46^{* * *}$ \\
$11-16$ & $1.51^{* * *}$ & $1.52^{* *}$ & $1.42^{* *}$ \\
$17-21$ & $1.42^{* *}$ & $1.53^{* *}$ & $1.45^{*}$ \\
$22-30$ & $1.67^{* * *}$ & $1.52^{*}$ & \\
\hline \hline
\end{tabular}

Author's analysis of Birth Cohort 70 data.

${ }^{* * *} \mathrm{p}<0.0001{ }^{* *} \mathrm{p}<0.01{ }^{*} \mathrm{p}<.0 .05+\mathrm{p}<0.10$

A similar story holds with respect to whether their first partnership had ended. Table 12 shows that the relative risks of partnership breakdown are significantly higher amongst those who had experienced a parental separation and that the risks did not vary much with the age of the child at the time of separation. Taking into account childhood factors did not change the story for either men or women. As in our comparative analyses we also took into account age at first partnership and type of first partnership i.e. whether it was a cohabitation or marriage. For the men adjusting for age at and type of first partnership does not noticeably alter the relative risks of partnership dissolution. Amongst the women there is clearer evidence that age at and type of first partnership are implicated in the heightened chances of experiencing 
partnership dissolution in adulthood, at least amongst those who experienced parental separation during childhood.

\section{Discussion}

The two main themes of this chapter were the rise of cohabitation and the legacy of parental divorce across nations and generations. With respect to cohabitation our cross-national analyses showed there was marked variation in the ways men and women were forming partnerships. In the 1990s, marriage was still the pre-eminent marker for entry into a first union in the southern European countries whereas in most western and northern European countries and in the USA cohabitation had eclipsed marriage as the marker for first partnership. We also showed that cohabiting unions tended to be short-lived affairs in that after five years only a minority of cohabiting unions remained intact, they had either converted into marriages or dissolved. Sweden was the only country where there was evidence of longer-term cohabitation. However, longer-term cohabitation may be becoming more prevalent in other nations. Since the early 1990s, when most of our comparative data were collected, there have been further increases in the level and duration of cohabitation in many countries. We also showed that with a few exceptions there is a discernible movement away from becoming a parent within marriage to having a first child within a cohabiting union, and that children born to cohabiting parents, especially those who did not subsequently marry, were more likely to see their parents separate than those born to married parents.

In many European countries and the USA, the recent marked rises in unmarried cohabitation and having children outside of marriage shows little sign of significant abatement, which raises questions about the hegemony of legal marriage and many of the assumptions on which public policies and even social scientific theories are built. Why are people excluding themselves from formal marriage and does it matter? The anxiety expressed in the literature (Waite and Gallagher, 2000) stems largely from the fact that at the present time cohabiting unions are more fragile than marital unions. However, this difference between the two types of unions may be largely due to the stronger and more committed partnerships being selected into marriage. Moreover, if the general trend and future course of cohabitation is for parents who live together to eschew marriage, then cohabitations, other things being 
equal, will become more durable alternatives to marriage. There are signs of this already happening in Sweden and France.

Across the nations considered here, the hallmarks of the adult demographic behaviour of children who experience parental separation are that they tend to form partnerships and become parents at young ages, they tend to choose cohabitation over marriage, and their own partnerships in turn are more likely to terminate. All these factors are in themselves inter-related in that, dissolution is more common amongst those who cohabit or have youthful partnerships or become parents at a young age, and youthful partnership increases the chances of youthful parenthood. In future work we hope to address the pathways through this demographic maze. Here, we have largely considered the individual components. The preference found across all the nations in our study to cohabit (and the accompanying risk of having a baby in such unions) amongst those who experienced a parental separation may represent reluctance on the part of young people with such experiences to make a permanent commitment, such as that enshrined in legal marriage. Additionally, it may be that parental divorce fosters a lower commitment to marriage (Amato, 1996; Amato and de Boer, 2001) and or more liberal attitudes to non-marital living arrangements (Thornton, 1991). At the macro-level rising divorce rates may well have increased the perceived risks of investing in marriage and the emergence of cohabitation may have been a logical response to this uncertainty.

In our longitudinal analysis using data from the 1970 cohort we tried to ascertain whether there were prior factors that might throw light on why the partnership and parenthood behaviour of children who had experienced parental separation might differ from their peers without such an experience. Thus far we have found few childhood factors that accounted for the associations between parental divorce and the adult demographic behaviour of their children, a result very similar to that found in our extensive analyses of the children born in 1958 (Kiernan, 1992; Kiernan, 1997; Cherlin, Kiernan and Chase Lansdale, 1995; Kiernan and Cherlin, 1999; Furstenberg and Kiernan, 2001; Kiernan, 2002). Our earlier studies based on the experiences of the 1958 cohort showed that adults whose parents had divorced during childhood were more likely to have no qualifications and more adverse economic situations in adulthood, but these differences were largely attenuated when we controlled for pre-divorce circumstances. However, just as we have seen for the 1970 cohort pre-divorce circumstances were less influential in 
accounting for why children who experienced parental divorce differed in their personal relationships and parenthood behaviour in adulthood. Further work is required to unearth the mechanisms and pathways that lie behind these findings.

Why are children from separated families more likely to form partnerships and perhaps more importantly for the welfare of themselves and their children become parents at a young age? There is some evidence from an analysis of the British National Survey of Sexual Attitudes and Lifestyles (Kiernan and Hobcraft, 1997) that an important proximal factor in youthful partnerships, perhaps not surprisingly was age at first sexual intercourse. Early age at first sexual intercourse was more prevalent amongst children who experienced parental divorce and they found that much of the earlier entry into first partnership among those whose parents had divorced derived from earlier sexual activity. If children with divorced parents delayed becoming sexually active they were no more likely to form partnerships at a young age than their peers who did not experience parental divorce. However, earlier sexual activity did not account for their early age at entry into parenthood. Reaching an understanding of why early parenthood is more common amongst children from separated families is important, as a raft of American and British studies have shown that these families do not fare well. Youthful parenthood is an issue of concern to policymakers both in the USA (Darroch, Frost and Singh, 2001) and Britain (Social Exclusion Unit, 1999). This is not the case in other western European nations. This may be due to the fact that teenage fertility rates have been substantially lower and exhibited more marked declines in recent times in these nations than has been the case in the in the USA and the UK. However a recent cross-national study using the European Community Household Panel Study by Berthoud and Robson (2001) has shown that young mothers and their families experience disadvantage in all of the 13 countries included in their analysis. Early sexual intercourse, partnerships and parenthood may be an understandable response to the social, economic and emotional uncertainties that are a frequent accompaniment to parental separation. Young people with such experiences may well have high hopes for their own family life but they tend for various reasons to have lower human, social and emotional capital for dealing with their own personal relationships and circumstances. High hopes and low capacities may well be an important feature of fragile relationships and vulnerable families, as has been 
shown to be the case in the US Fragile Families Study (McLanahan, Garfinkel et al, 2001).

One of the most important issues to arise from our comparative analysis, and one worthy of further investigation, is why unions are more fragile in some countries than in others? For example the United States and Great Britain stand out as having high dissolution rates, especially amongst families with children and solo motherhood is more commonplace. As a consequence American and British fathers are likely to figure less in the daily lives of their children than their European counterparts. Why do parents in United States and Britain find it more difficult to stay together? What are the constraints that hinder the continuation of relationships? Finding the answer to such questions will be an important step in reducing uncertainty and disadvantage in the lives of our children.

If parental separation continues to echo through to the next generation then more and more children will experience parental separation. Our analysis suggests that the salient legacies of parental divorce in one generation on the lives of their children and grandchildren are more likely to arise from the predisposition to early parenthood and partnership dissolution in the second generation, and to a lesser extent from the tendency to form youthful partnerships and to cohabit. The developments in cohabitation and divorce that we have examined in this chapter have clearly shown that the primacy of marriage as the basis of family life has already been significantly eroded (albeit to different degrees across nations) and that public policies can no longer be built upon a notion of legal, life-long, co-residential unions. 


\section{References}

Amato, P.R. (1996), 'Explaining the intergenerational transmission of divorce', Journal of Marriage and the Family, 58: 628-640

Amato, P.R. and DeBoer, D.D. (2001), 'The transmission of marital instability across generations: Relationship skills or commitment to marriage?', Journal of Marriage and the Family, 63: 1038-1051

Booth, A. and Crouter, A. (eds.) (2002), Just Living Together: Implications of cohabitation on families, children and social policy. New Jersey: Lawrence Erlbaum Associates, Inc.

Berthoud, R. and Robson, K. (2001), The outcomes of teenage motherhood in Europe. Mimeo, Institute of Social and Economic Research, University of Essex

Butler, N., Dowling, S. and Osborn, A. (1970), Child Health and Education Study: Five Year Follow-up. Colchester: ESRC Data Archive

Bynner, J., Ferri, E. and Shepherd, P. (eds.) (1997), Twenty-something in the 1990: Getting on, getting by, getting nowhere. Aldershot: Aldgate

Bynner, J., Ferri, E., Shepherd, P. and Smith, K. (2000), The design and conduct of the 1999-2000 surveys of the National Child Development Study and the 1970 British Cohort Study. London: Institute for Education, Centre for Longitudinal Studies

Cherlin, A., Kiernan, K.E. and Chase-Lansdale, P.L. (1995), 'Parental divorce in childhood and demographic outcomes in young adulthood', Demography, 32: 299-318

Council of Europe (1999), Recent Demographic Developments in Europe. Strasbourg: Council of Europe

Darroch, J., Frost, J.F. and Singh, S. (2001), Teenage Sexual and Repoductive Behavior in Developed Countries. New York: Alan Guttmacher Institute

Festy, P. (1980), 'On the new context of marriage in Western Europe', Population and Development Review, 6(2): 311-315

Furstenberg, F.F.and Kiernan, K.E. (2001), 'Delayed Parental Divorce: How much do children benefit?', Journal of Marriage and the Family, 63(2): 446-457 
Glenn, N.D. and Kramer, K.B. (1987), 'The marriages of and divorces of children of divorce', Journal of Marriage and the Family, 49: 811-825

Haskey, J. (2001), 'Demographic Aspects of Cohabitation in Great Britain', International Journal of Law Policy and the Family, 15: 51-67

Hetherington, E.M., (forthcoming), 'The Intergenerational Transmission of Couple Instability', in Chase-Lansdale, P.L., Kiernan, K.E. and Friedman, R. (eds.), Human Development across Lives and Generations: The potential for change. Cambridge: Cambridge University Press

Hobcraft, J.N. (1998), Intergenerational and Life Course Transmission of Social Exclusion, CASEpaper 15. London: London School of Economics

Kiernan, K.E. (1986), 'Teenage marriage and marital breakdown: A longitudinal study", Population Studies, 40(1): 35-54

Kiernan, K.E. (1997), The Legacy of Parental Divorce: Social, economic and demographic experiences in adulthood, CASEpaper 1. London: London School of Economics

Kiernan, K.E. (1992), 'The Impact of Family Disruption in Childhood on Transitions made in Young Adult Life', Population Studies, 46(2): 213-234

Kiernan, K.E. (2001), 'Partnership Formation and Dissolution in Western Societies', in Smelser, N. and Baltes, P. (eds.), Encyclopaedia of Social and Behavioral Sciences. Oxford: Pergamon

Kiernan K.E. (2002), 'Demography and Disdavantage: Chicken and Egg?', in Hills, J., Le Grand, J. and Piauchaud, D. (eds.), Understanding Social Exclusion. Oxford: Oxford University Press

Kiernan, K. and Hobcraft, J.N. (1997), 'Parental divorce during childhood: Age at first intercourse, partnership and parenthood', Population Studies, 51(1)

Kiernan, K.E. and Cherlin, A. (1999), 'Parental divorce and partnership dissolution in adulthood: Evidence from a British birth cohort study', Population Studies, 53: 39-48

Kiernan, K.E. and Mueller, G. (1999), 'Who divorces?', in McRae, S. (ed.), Changing Britain: Families and Households in the 1990s. Oxford: Oxford University Press 
International Journal of Law, Policy and the Family (2001), Special Issue: Unmarried Cohabitation in Europe, 15(1)

McLanahan, S. and Bumpass, L. (1988), 'Intergenerational Consequences of Family Disruption', American Journal of Sociology, 94: 130-52

McLanahan, S., Garfinkel, I., Reichman, N., and Teitler, J. (2001) ‘Unwed Parents or Fragile Families? Implications for welfare and child support policy', in $\mathrm{Wu}, \mathrm{L}$. and Wolfe, B. (eds.), Out of Wedlock: Causes and consequences of nonmarital fertility. New York: Russell Sage Foundation

Mueller, C.W. and Pope, H. (1977), 'Marital instability: A study of its transmission between generations', Journal of Marriage and the Family, 39: 83-93

Noack, T. (2001), 'Cohabitation in Norway: An accepted and a more regulated way of living', International Journal of Law Policy and the Family, 15: 102-117

Prinz, C. (1995), Cohabiting, Married, or Single. Aldershot: Ashgate Publishing

Raley, R.K. (2000), 'Recent trends and differential in marriage and cohabitation: The United States', in Waite, L. et al (eds.), The Ties that Bind: Perspectives on marriage and cohabitation. Hawthorne, New York: Aldine de Gruyter

Richman, N. (1978), 'Depression in mothers of young children', Journal of the Royal Society of Medicine, 71: 489-493

Rutter, M., Tizard, J. and Whitmore, K. (1970), Education, Health and Behaviour. London, Longman

Rutter, M., Tizard, J., and Graham, P. (1976), 'Isle of Wight Studies: 19641974', Psychological Medicine, 16: 689-700

Social Exclusion Unit (1999), Teenage Pregnancy, CM 4342. London: The Stationery Office Ltd

Thornton, A. (1991), 'Influence of Marital History of Parents on the Marital and Cohabitational Experiences of Children', American Journal of Sociology, 96: 868-94

United Nations (1992), Questionnaire and Codebook Fertility and Family Surveys in Countries of the ECE Region. New York: United Nations 
United Nations Economic Commission for Europe (1996-99), Fertility and Family Surveys in Countries of the ECE Region. Economic Studies, No.10h, Geneva: United Nations

Waite, L., Bachrach, C., Hindin, M., Thomson, E., and Thornton, A. (eds.) (2000), Ties that Bind: Perspectives on Marriage and Cohabitation. Hawthorne, New York: Aldine de Gruyter

Waite, L. and Gallagher, M. (2000), The Case for Marriage. New York: Doubleday

White, L. (1990), 'Determinants of Divorce: A review of research in the eighties', Journal of Marriage and the Family, 52(4): 904-12 